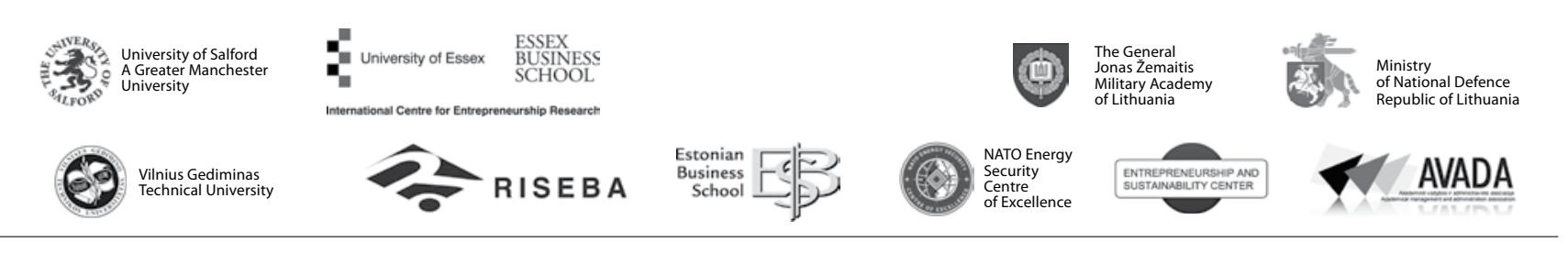

\author{
JOURNAL OF SECURITY AND SUSTAINABILITY ISSUES \\ ISSN 2029-7017 print/ISSN 2029-7025 online \\ 2017 March Volume 6 Number 3 \\ http://dx.doi.org/10.9770/jssi.2017.6.3(13)
}

\title{
COMPETITIVE AND SUSTAINABLE TECHNOLOGICAL DEVELOPMENT: FOCUS ON BUSINESS ENTERPRISES
}

\author{
Alexandr Teletov ${ }^{1}$, Yeugene Nagornyi ${ }^{2}$, Nataliia Letunovska ${ }^{3}$, Olena Shevliuga ${ }^{4}$ \\ ${ }_{1,2,3,4}$ Sumy State University \\ Rymskii-Korsakiv str. 2, 40007 Sumy, Ukraine \\ E-mails:'teletov@yandex.ru; $780317 @ u k r . n e t ;{ }^{3}$ n.letunovska@gmail.com; ${ }^{4 h}$ elenshevluga@gmail.com
}

Received 10 October 2016; accepted 10 January 2017

\begin{abstract}
The article deals with innovative and sustainable strategies and approaches to the implementation of technical and technological development at the enterprises in order to strengthen their competitive position in the market and to boost their economic security. We employ the case study of Ukraine in order to provide a practical example of enterprise development. Our paper analyzes Ukraine's position in the global competitive environment. Moreover, we show the relationship between the technical, technological, and innovative development of enterprises and draw some conclusions from that comparisons. Based on our analysis and our empirical results, we propose several measures aimed at increasing the level of technical and technological development.
\end{abstract}

Keywords: technological development, innovative strategy, enterprise development, technical solution, economic activity

Reference to this paper should be made as follows: Teletov, A.; Nagornyi, Y.; Letunovska, N.; Shevliuga, O. 2017. Competitive and sustainable technological development: focus on business enterprises, Journal of Security and Sustainability Issues 6(3): 491-500. http://dx.doi.org/10.9770/jssi.2017.6.3(13)

JEL Classifications: M11, O32

\section{Introduction}

Competitive and sustainable economic development nowadays based on activation of innovation, introducing new technologies and improving product desirability in the internal and external markets (Laužikas et al. 2016; Baronienė, Žirgutis 2016; Kaźmierczyk, Aptacy. 2016; Jurevičienė, Skvarciany 2016; Čirjevskis 2016).

Production upgrading is based on innovative ideas, technical and technological solutions (Ahmed et al. 2017; Crosbie et al. 2017; Mouraud 2017; Barberis et al. 2017; Rezk et al. 2015). Innovative development is closely linked not only to the operation of industrial enterprises, but also to all spheres of society (García-Fuentes; De Torre 2017; Perfido et al. 2017; Daher et al. 2017; Boonyachut 2016).

Worn-out fixed assets cannot provide high-quality performance of products that would allow it to reach a sufficient competitive level, so it is necessary to develop new advanced technologies. An important question that arises today before market entities (state, region or enterprise) is the selection of products, which is planned to produce, conformity of products with international quality and safety standards. The aim of our paper is to examine the relationship between innovation and technical and technological development of enterprises and to analyze technological innovation features. 


\section{The innovative development of Ukraine: technological aspects}

The development of Ukraine in today's conditions caused by the necessity to intensify innovation in all spheres of economic activity. The relevance of this issue is confirmed by the international ratings of the country and approved at the state level in the Concept of scientific, technological, and innovative development of Ukraine.

The problems of innovative activity intensification in Ukraine and its dynamics were analyzed in a number of scientific works, authors of which argued the need to develop innovation management system and provided recommendations on promising areas of its development (see Khaustova 2016). There problems seem to resemble those in other countries in transition (Abrhám et al. 2015; Koudelková et al. 2015; Kalyugina et al. 2015; Strielkowski, Weyskrabova 2014).

If in 2012, Ukraine ranked $71^{\text {th }}$ in the rating of Global Competitiveness Index, then in 2013 there was a fall in its rating by as much as 22 positions. According to the Global Innovation Index 2013 (position in innovative factor) Ukraine took $71^{\text {th }}$ place among 142 countries (it is 8 positions lower than in 2012) (Ukrainian National Competitiveness Report, 2013). The alternative investigation Global Innovation Index (made by Boston Consulting Group and National Association of Manufacturers), which assesses the ability of businesses to stimulate the development of innovation, in 2016 Ukraine was on the $56^{\text {th }}$ place among 128 countries (The Global Innovation Index, 2016).

According to the Bloomberg Innovation Index, in 2015 (published by news agency Bloomberg based on the data of international organizations) Ukraine was on the $33^{\text {th }}$ place among 50 countries, noteworthy that for manufacturing component is on the last place (The Bloomberg Innovation Index, 2015).

According to the World Economic Forum in 2015 Ukraine's position in the global competitiveness index dropped to $85^{\text {th }}$ place among 138 countries. According to the Global Innovation Index in 2015 Switzerland, for instance, was at the $1^{\text {th }}$ place, United States of America is at the $5^{\text {th }}$ place, Germany - at the $12^{\text {th }}$ place, Czech Republic - at the $24^{\text {th }}$ place. Ukraine was at the $64^{\text {th }}$ place among 141 countries (The Global Innovation Index, 2015). One of the most notorious problems of Ukraine (as well as other economies in transition) is for example corruption (Čábelková, Strielkowski 2013).

In 2015, Ukraine had several competitive advantages for innovation: by the availability of scientists and engineers, the quality of scientific research institutions and the number of patents. To enhance the innovative component of the economy there is a need to increase the volume of public procurement of high-tech products and improve collaboration between business and universities in the areas of science and innovation. According to the State Statistics Committee of Ukraine exploration of the production of innovative products in the country is faster than development of new processes. Indicator of new processes implementation is unstable. It increased during 2007-2011, but from 2012 to 2015 it was observed its gradual decline (Fig. 1). Maximum number of embedded processes was 2510 units in 2011. 


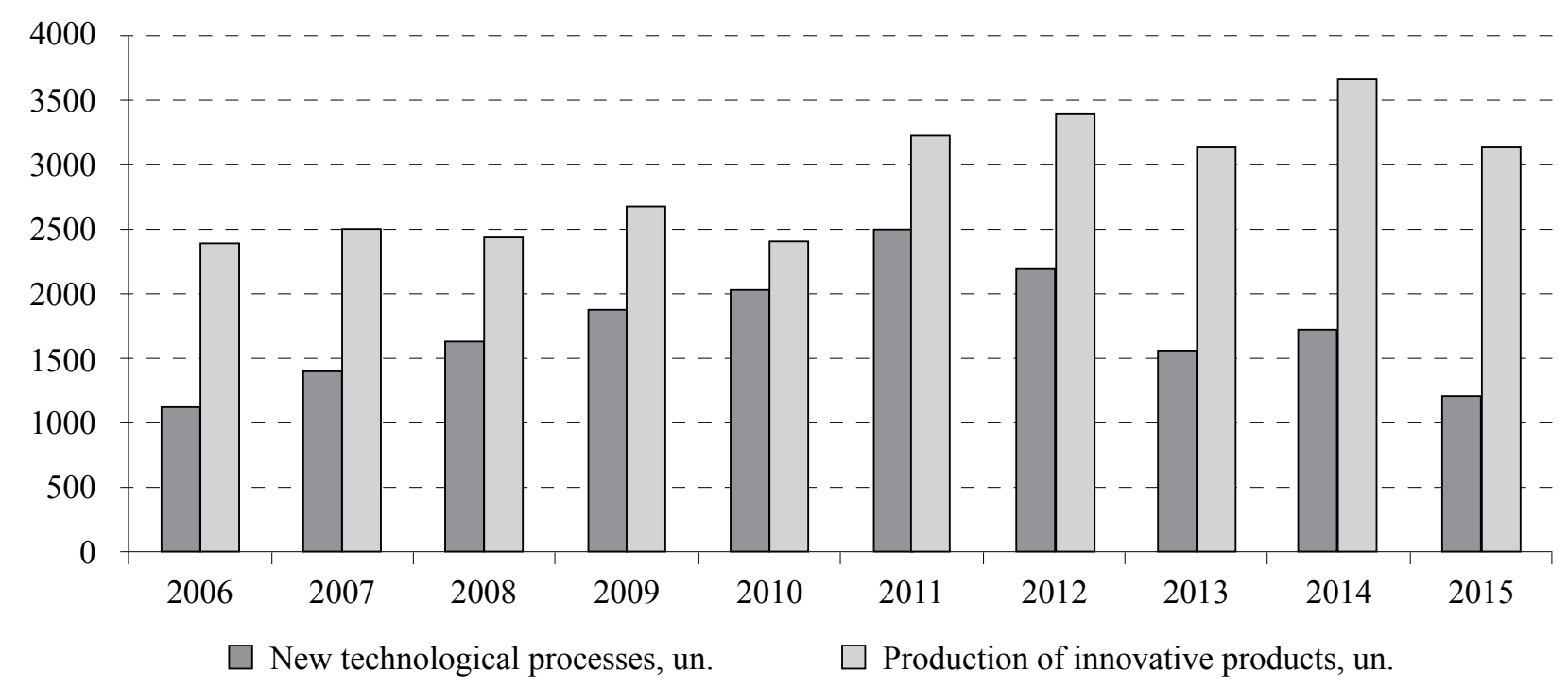

Fig. 1. The implementation of new technological processes and development of new products in industry of Ukraine Source: Own results based on the State Statistics Service of Ukraine (2016)

\section{Theoretical background}

Yefremov (2012) highlights the concept of innovative technology development of an enterprise, which is defined as its irreversible logical change, due to the design and development of new technologies and relevant technical improvements based on the use or creation of new knowledge, organizational, economic and institutional reforms, therefore it is formed a qualitatively new technological system that provides competitive levels of efficiency and production safety. This is valid for enterprises in virtually any sector of the economy (Lisin, Strielkowski 2014).

Innovative development is examined as the development that involves continuous search and the use of new methods and areas of enterprises' potential realization in changing environmental conditions. It is associated with the modification of existing and formation of new markets (see e.g. Illiashenko et al. 2015).

An innovative enterprise development is often considered as a process of directed changes of the enterprise, depending on the innovation potential of the company. The source of it is innovations that create new opportunities for follow-up of an enterprise on the market by implementing the ability to find new solutions, ideas resulting in the inventions (see e.g. Danilina et al. 2013). Clusters play important role in technological advance of enterprises (Ignatavičius et al. 2015; Tvaronavičiené, Černevičiūtè 2015; Tvaronavičienė et al. 2015a; 2015b; Fuschi, Tvaronavičienė. 2016; Tvaronavičienė 2016; Razminienè et al. 2016).

Lihonenko (2016). identifies the following structure of technology development of a company:

- Preparatory phase, which involves the creation of intellectual background (intellectual support) of technological development (personnel training, scientific research funding).

- The main phase, during which technologies directly arise and conditions for their implementation (initialization of new technologies and the materialization of technology, technology personalization) are created.

- The final phase, which is associated with commercialization of the developed or involved new technologies in practice, and also protection of own developed technologies, results of product and process innovation, acquiring of property rights to the objects of intellectual property. 
Innovations are intended to enhance the competitiveness of each country and improve the lives of every individual. They are aimed at the fast and steady economic development. The problems of innovation, the current introduction of new technology or technological innovations, the impact of innovation on the marketing strategy of the enterprise, commercialization and diffusion of innovation and the opportunities opened up by technical and technological innovations, were investigated in a number of scientific works (see e.g. Arranz et al. 2009; Garcia R. et al. 2002; Hall et al. 2003; Johansson et al. 2007; Lawson et al. 2001).

\section{Modern technological development at enterprises: authors' investigation}

Modern technology has certain development trends and application. The main ones are: the transition to new processes by combining in a single technological complex several operations that were previously carried out separately; providing new technological systems or low-waste production; increasing the level of complexity of mechanical lines; the use of new technological processes of microelectronics facilities, allowing both to increase the degree of automation of processes and achieve a more dynamic flexibility.

Innovative and technical and technological ways of development is quite complex processes, which is a necessary condition of use and innovation. The objectives of an enterprise in this case are: new resources and personnel; new products (services); new technologies; new forms of management; new markets. These ways are caused by internal and external factors. Internal factors are involved in the production and economic activities of the enterprise: the basic and working capital of an enterprise, material, human and financial resources, production technology, management of an enterprise, opportunities for the introduction of innovations and so on.

According to the Institute of Economics and Forecasting of the National Academy of Sciences data, a significant proportion (almost $97 \%$ ) of technologies in Ukraine are of the third technological mode (metals, chemicals and agricultural sector) and fourth (petrochemicals, energy, heavy engineering) technological mode. All of them are technologies of mid-twentieth century. Only $3 \%$ of them are connected with the fifth and sixth modes (electronics, computers and telecommunications equipment, software, robotics, information services, and biomedical engineering) (Institute of Economics and Forecasting of the National Academy of Sciences). These technologies for at least one order increase added value per unit of output, revenues to the state budget and promote economic development of the country. This is the experience of developed countries (for example USA, Japan, countries of the European Union), in which GDP growth up to $90 \%$ is carried out due to of innovation factors, including technical and technological innovations.

Undoubtedly, this situation in Ukraine will not maintain the competitiveness of domestic enterprises for a long time. At present Ukraine's share in world trade volume of high technology products is very low - only $0.1 \%$ (Innovatsiina Ukraina, 2015).

In Ukraine, the national income by 50 - $60 \%$ of its volume consists of revenue from sale of resources, not high-tech products.

It should be noted that among innovation active enterprises in industry essentially dominate the entities with technological innovations (Fig. 2). 


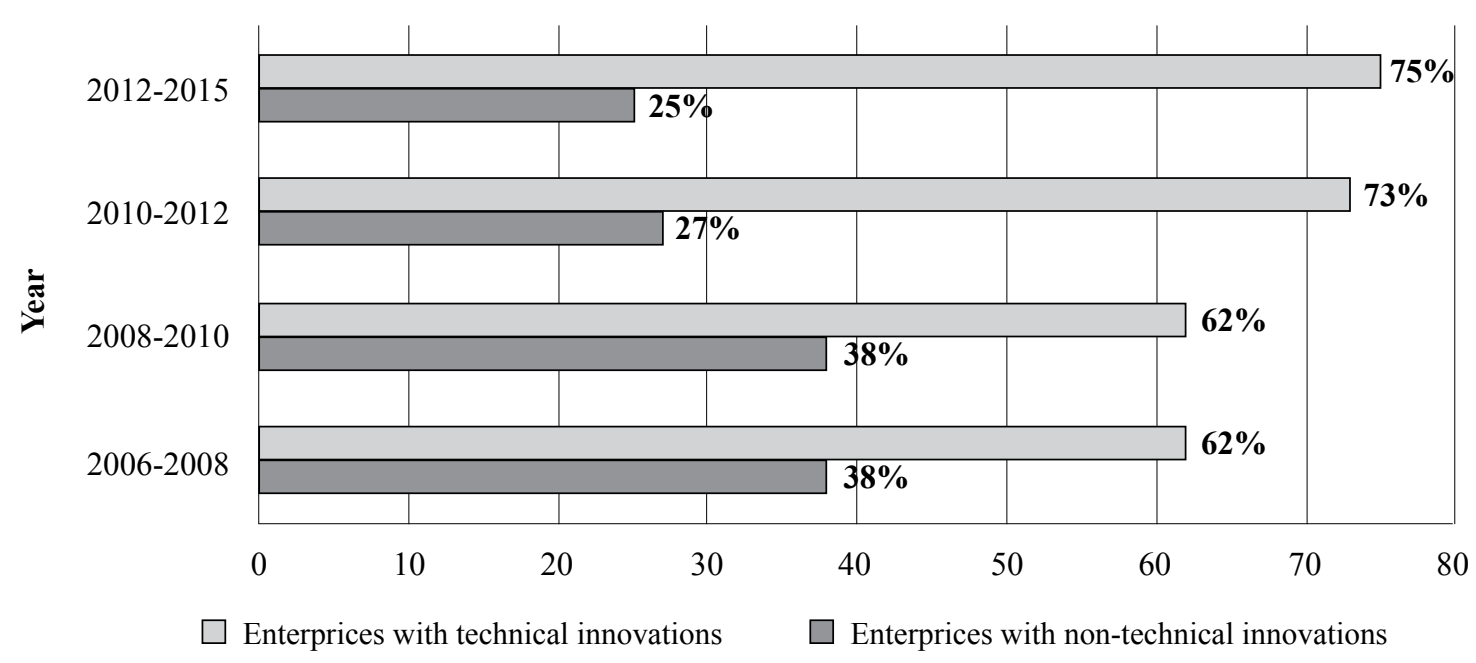

Fig. 2. Division of innovation active enterprises in Ukraine by the type of introduced innovations in activity

Source: Own results base on the State Statistics Service of Ukraine (2016)

In the area of business process management of enterprise, specific features of technological innovations are taken into account that allows clearly define the role of the enterprise directly in conjunction with contractors of enterprise's microenvironment. Enterprise controls the entire process, starting with the idea of implementing new technologies to the evaluation of the results of its implementation.

The scheme of interaction between internal and external environment on innovation and technical and technological ways of development is presented in Fig. 3.

Thus, innovative company aims are consistent with the aims and objectives of the technical and technological development of the company because they are aimed at the implementation and intensification of innovative activity at the enterprise. Innovation objectives are achieved by means of innovation. Because of technical and technological development it is considered as the direction of innovation development, the listed objectives overlap. Outside economy, the level of competition in the industry, the political situation and legislation, market of technologies, society and the level of innovation in general affects the enterprise. Changes connected with the influence of environmental conditions are displayed to innovation and business activities of enterprises, as well as directly to the technical and technological development way of the company. The main features of modern technical and technological development are the proliferation of high-tech and knowledgeintensive production increase. Its implementation contributes to sustainable economic growth of the enterprise, engaging their leadership position in the market, innovation, accumulation of new knowledge and information, and obtaining higher revenues.

Technical and technological development of the of industrial enterprises in the current economic conditions is essential, it makes possible to constantly products update, to improve quality, thereby enhancing the competitiveness of products and the enterprise in the market. Following the sequence of management process of technical and technological development, the company's management is able to accept and coordinate the timely management decisions to improve the results of its activities according to the chosen overall development strategy. 

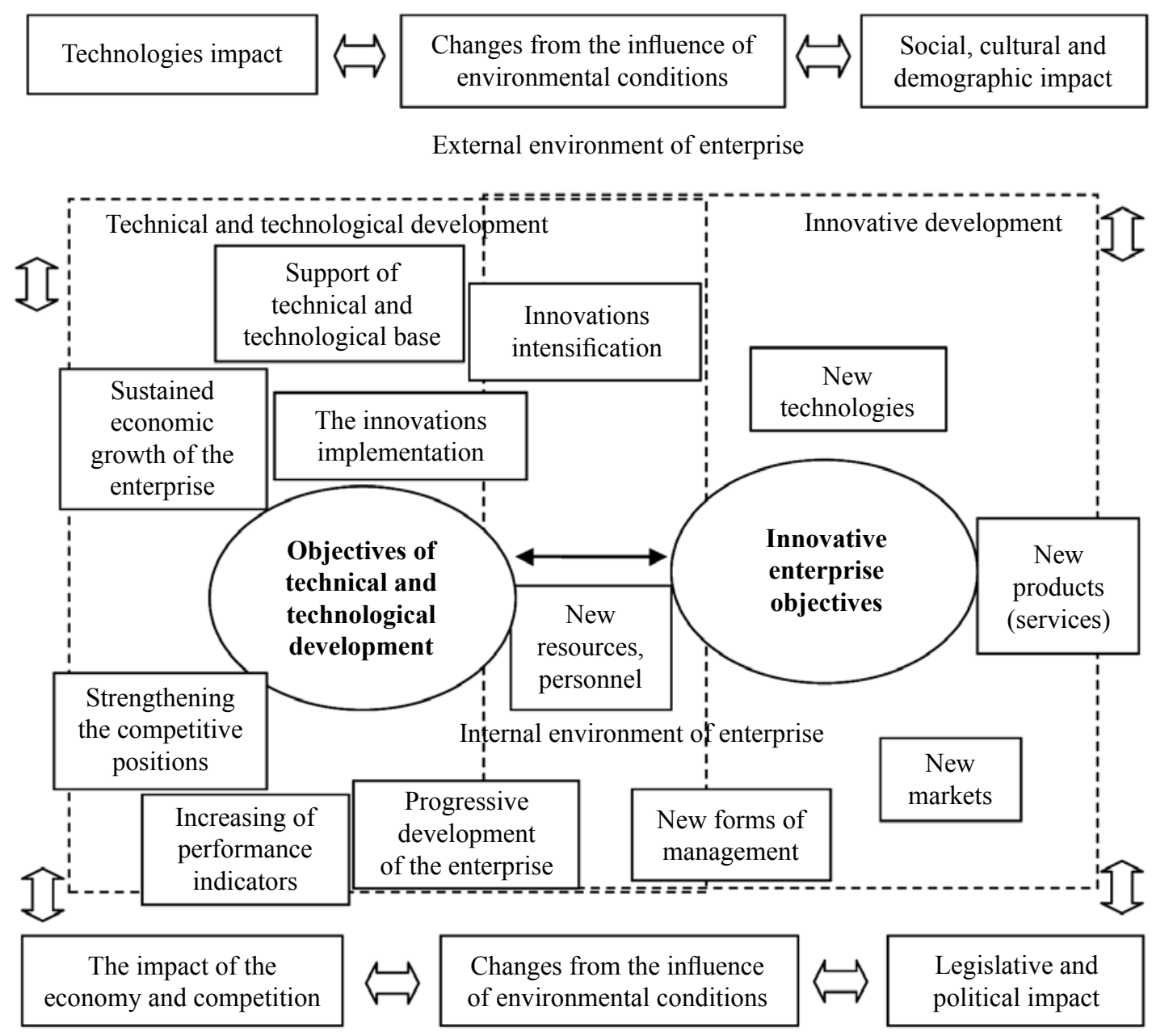

$\longleftrightarrow$ Mutual solution of objectives

Changes from the influence of environmental conditions

Fig. 3. The scheme of interaction between internal and external environment on innovation and technical and technological ways of development

Source: Own results

Some years ago, technological innovations were related to improving and they were given secondary importance, as the novelty of consumer properties of products on the market was considered important that is product innovations were more valuable. The technological innovations still have ahead role as new technology provides a review of all components of the innovations implementation process at the enterprise. The important point is not only the product and demand for it in the market, namely the technology of its production. Interconnection of innovations for the substantive content is shown in Fig. 4.

Technological innovations have the most significant influence on other innovations, they are the element that connects other innovations. New advanced technology allows the production of a new product or improves existing one in the application of sufficient scientific and technical base, new material resources, which is not possible using the old (traditional) technology. Technological innovations influence the organizational and managerial: organizational structure becomes more flexible, the style of leadership - democratic. New methods of management are used, new selection of personnel ready for innovations is possible, and generally, the interests of all participants in the innovation process are taken into account with the possibility of adjusting the planned solutions. 


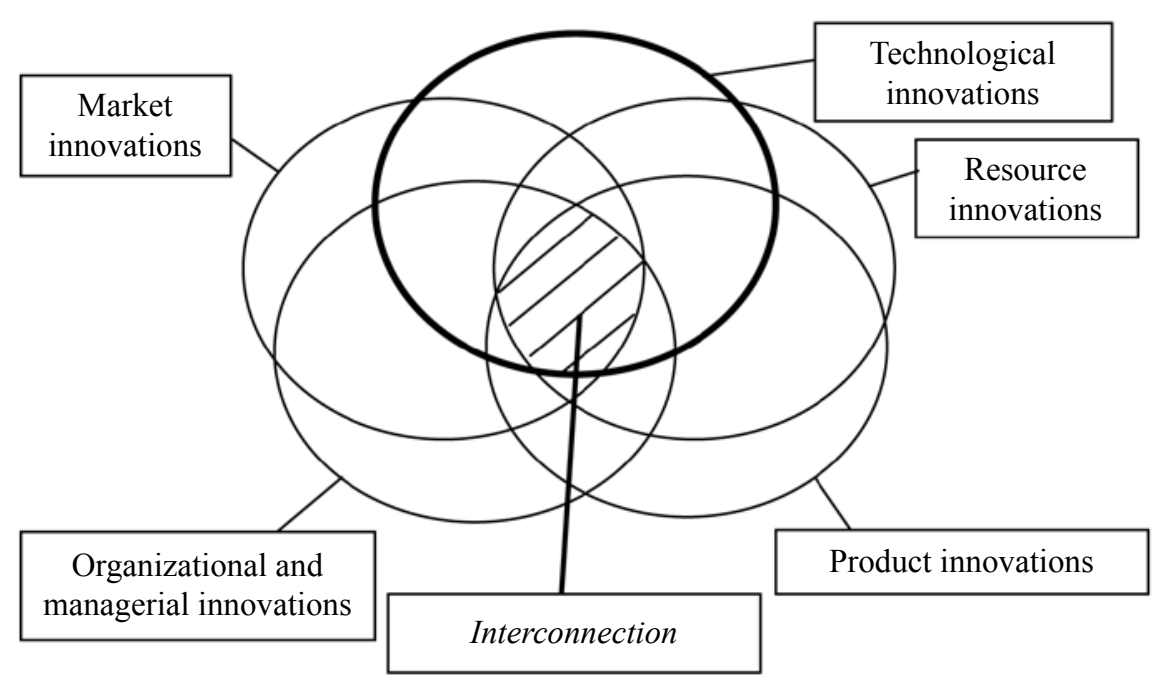

Fig. 4. Interconnection of innovations for the substantive content

Source: Own results

The impact of technological innovation on the resource ones caused by the fact that in any case the new production technology is based on use of new or significantly improved resource analogues, or is aimed at a more efficient extraction of the old resources or extraction of fundamentally new, those that could not be extracted in the absence of technical possibilities. The company, which implements technological innovations is focused on new markets, extends beyond national level to international.

Thus, technological innovation improves the quality of the product creates its new modification. It can be focused on improving productivity. This is achieved due to increases in volumes (generally in the same or slightly increased costs) for production of product with traditional quality. Technological innovation can also be aimed at sharply reduce the cost of the product, which enables reduction in price and gaining advantages in the competition. In both cases, technological innovation increases sales of already known products or creates new products. Analysis of technical systems has shown that technological innovation causes impact on the «speed» of a new product output on the market, because it is necessary to evaluate not only the potential of the new technology, but also the impact of investments compared to the former technology.

Innovative management tools are considered as those that are used to develop and implement programs and projects related to the introduction of new forms of interaction between enterprises and organizations (see Fedorchak 2012):

- outsourcing - the transfer of designated functions by organization to another company specializing in the relevant field;

- benchmarking - studying the best practices in management and implementation of its own activities;

- reengineering - a fundamental rethinking of activity and appropriate actions to achieve sharp, radical changes.

The tools of innovation policy, which directly affect the enterprise are conventionally divided into general and special. Common tools include those by which favorable for the emergence and innovation climate creates, and the special - those intended to influence the specific scope of the technologies or specific companies or research institutions that are involved in creating and implementing innovations (see Berezhanskyi 2013).

The model of creating technical and technological innovations is submitted that will determine the potential of economic growth and will be the starting point for the evaluation process. Model of technical and technological innovations will be used at the industrial enterprises, which are interested in new products and processes development. In this case, innovational activity is seen from the perspective of key factors: human, processes, tools and technologies. The model has the following key objectives (see e.g. Aleksandravicius et al. 2008): 
- risk assessment;

- methods for creating technical and technological innovations;

- return on investment.

As experience of foreign countries has shown, a major role in activation of scientific and technological development of industrial enterprises of Ukraine and other countries the state should play, creating favorable conditions for industrial companies scientific and research activities, implementing different types of tax and depreciation benefits. Despite a much larger share of own funds of enterprises for their own development of innovations, knowledge-based domestic production is low $(0.3 \%)$, while one-third of funds is spent on the purchase of new equipment and not on the acquisition of intellectual property rights on some innovative inventions which is typical for companies in developed countries.

In many developed countries, a rather widespread method of financing innovation activity is represented by the venture capital funding (see Kerr et al. 2014). One of the most active venture capital funds operating in Ukraine is the fund Western NIS Enterprise Fund. It implements a broad program of private investment by means contributions to the charter capital, loans, leasing, technical assistance and other measures to promote the development of small and medium private enterprises. Its strategy is direct investments (direct purchase of ordinary shares) and investments in debt securities of private companies with their growth prospects.

\section{Conclusions}

Using the analysis of trends in key indicators related to the introduction of innovation in industrial countries for effective technical and technological innovation and development of machine-building enterprises the following steps might in principle increase the sustainability and the technological competitiveness of the Ukrainian business enterprises that are undergoing severe structural changes and facing economic transition and the related issues and problems:

- to assess the possibilities for enterprises to introduce innovations;

- to develop a strategy of investing in innovation and technical and technological development of enterprises;

- to develop a number of new sectors and industries, new types of machinery, equipment, instruments and devices, new management tools, automated and robotic systems;

- to intensify the processes of production updating and technical re-equipment of industrial sectors.

Thus, the achievement of innovation and technical and technological development, business activity level as close as possible to the world, will be the basis for the competitive advantages of Ukraine's enterprises, stable financial status and success of further operation.

\section{References}

Abrhám, J.; Bilan, Y.; Krauchenia, A.; Strielkowski, W. 2015. Planning horizon in labour supply of Belarusian small entrepreneurs, Economic Research-Ekonomska Istraživanja 28(1): 773-787. https://doi.org/10.1080/1331677X.2015.1084238

Ahmed, A.; McGough, D.; Mateo-Garcia, M. 2017. Testing innovative technologies for retrofitting: Coventry University as a living lab, Entrepreneurship and Sustainability Issues 4(3): 257-270. http://dx.doi.org/10.9770/jesi.2017.4.3S(2)

Aleksandravicius, P.; Staskevicius, J.A. 2008. Process of stucturization of technical-technological innovations, Industrial engineering. Available on the Internet $<$ http://innomet.ttu.ee/daaam08/Online/Engineering\%20Management/Aleksandravicius.pdf $>$.

Arranz, N.; Arroyabe, J. 2009. Technological cooperation: a new type of relations in the progress of national innovation systems, The Innovation Journal: The Public Sector Innovation Journal 14(2): 1-11.

Barberis, S.; Roncallo, F.; Traverso, A. 2017. Towards innovative district energy management: a case study with stochastic renewable generators, Entrepreneurship and Sustainability Issues 4(3): 294-309. http://dx.doi.org/10.9770/jesi.2017.4.3S(5)

Baronienè, L.; Žirgutis, V. 2016. Management decisions for sustainable development: medical software case study, Entrepreneurship and Sustainability Issues 4(2): 129-145. http://dx.doi.org/10.9770/jesi.2016.4.2(2) 
Berezhanskyi M.M. 2013. Instrumenty zapezpechennia innovatsinoho rozvytku ekonomiky, Akademichnyi ohliad 2(39): 21-29. Bloomberg Innovation Index 2015. Available on the Internet $<$ https://www.bloomberg.com/graphics/2015-innovative-countries/>.

Boonyachut, S. 2016. Sustainability of community's entrepreneurship: case of floating market at Ladmayom, Entrepreneurship and Sustainability Issues 4(2): 211-219. http://dx.doi.org/10.9770/jesi.2016.4.2(8)

Č́belková, I; Strielkowski, W. (2013). Is the level of taxation a product of culture? A cultural economics approach, Society and Economy 35(4): 513-529. https://doi.org/10.1556/SocEc.2013.0007

Čirjevskis, A. 2016. Sustainability in information and communication technologies’ industry: innovative ambidexterity and dynamic capabilities perspectives, Journal of Security and Sustainability Issues 6(2): 211-226. http://dx.doi.org/10.9770/jssi.2016.6.2(2)

Crosbie, T.; Short, M.; Dawood, M.; Charlesworth, R. 2017. Demand response in blocks of buildings: opportunities and requirements, Entrepreneurship and Sustainability Issues 4(3): 271-281. http://dx.doi.org/10.9770/jesi.2017.4.3S(3)

Daher, E.; Kubicki, S.; Guerriero, A. 2017. Data-driven development in the smart city: Generative design for refugee camps in Luxembourg, Entrepreneurship and Sustainability Issues 4(3): 364-379. http://dx.doi.org/10.9770/jesi.2017.4.3S(11)

Danilina H.; Mingaleva, Zh. 2013. Improving of innovation potential efficiency of industrial enterprises, Middle-East Journal of Scientific Research (Socio-Economic Sciences and Humanities) 13: 191-194.

Fedorchak O.V. Innovatsiini instrumenty upravlinnia tsilovymy prohramamy ta proektamy Available on the Internet $<$ http://www.kbuapa.kharkov.ua /e-book/db/2012-2/doc/1/10.pdf>.

Fuschi, D. L.; Tvaronavičienė, M. 2016. A network based business partnership model for SMEs management, Entrepreneurship and Sustainability Issues 3(3): 282-289. http://dx.doi.org/10.9770/jesi.2016.3.3(5)

Garcia, R.; Calantone, R. 2002. A critical look at technological innovation typology and innovativeness terminology: a literature review, The Journal of Product Innovation Management 19: 110-132.

García-Fuentes, M. A.; De Torre, C. 2017. Towards smarter and more sustainable regenerative cities: the REMOURBAN model, Entrepreneurship and Sustainability Issues 4(3): 328-338. http://dx.doi.org/10.9770/jesi.2017.4.3S(8)

Global Innovation Index 2015. Available on the Internet <https://www.globalinnovationindex.org/gii-2016-report>.

Global Innovation Index 2016. Available on the Internet <https://www.globalinnovationindex.org/analysis-indicator>.

Hall B.; Khan, B. 2003. Adoption of new technology. New Economy Handbook. Available on the Internet <http://citeseerx.ist.psu.edu/ viewdoc/download?doi=10.1.1.202.5561\&rep=rep1\&type $=$ pdf $>$.

Ignatavičius, R.; Tvaronavičienė, M.; Piccinetti, L. 2015. Sustainable development through technology transfer networks: case of Lithuania, Journal of Security and Sustainability Issues 4(3): 261-267. http://dx.doi.org/10.9770/jssi.2015.4.3(6)

Illiashenko, S.M.; Shypulina, Yu.S.; Illiashenko, N.S. 2015. Theoretic and methodic grounds to provide mutually coordinated interconnection between strategic and project management of innovations at the enterprise, in Barcik, Agnieszka, Honorata, Howaniec, Zbigniew, Malara (Ed.). Current problems in management. Bielsku-Białej: Wydawnictwo Akademii Techniczno-Humanidtycznej, 17-30.

Innovatsiina Ukraina 2020: natsionalna dopovid 2015, in Heiets V.M. (ed.). Kyiv: NAN Ukrainy.

Institute for economics and forecasting of National Academy of Sciences of Ukraine. Available on the Internet $<$ http://ief.org.ua $>$.

Johansson, B.; Karlsson, C.; Backman, M. 2007. Innovation policy instruments CESIS. CESIS Electronic Working Paper Series 105: 32.

Jurevičienè, D.; Skvarciany, V. 2016. Camels+t approach for banks' assessment: evidence from the Baltics, Entrepreneurship and Sustainability Issues 4(2): 159-173. http://dx.doi.org/10.9770/jesi.2016.4.2(4)

Kalyugina, S.; Strielkowski, W.; Ushvitsky, L.; Astachova, E. 2015. Sustainable and secure development: Facet of personal financial issues, Journal of Security and Sustainability Issues 5(2): 297-304. https://doi.org/10.9770/jssi.2015.5.2(14)

Kaźmierczyk, J.; Aptacy, M. 2016. The management by objectives in banks: the Polish case, Entrepreneurship and Sustainability Issues 4(2): 146-158. http://dx.doi.org/10.9770/jesi.2016.4.2(3)

Kerr, W.R.; Nanda, R. 2014. Financing Innovation. Harvard University and NBER. Available on the Internet <http://www.hbs.edu/ faculty/Publication \%20Files/15-034_c08817a4-7eac-4c62-b58b-8632585180b5.pdf>. 
Khaustova, K.M. 2016. Estimation the impact of macroeconomic factors on the innovation activities of enterprises in Ukraine, Marketing and Management of Innovations 3: 180-190.

Koudelková, P.; Strielkowski, W.; Hejlová, D. 2015. Corruption and System Change in the Czech Republic: Firm-level Evidence, DANUBE: Law and Economics Review 6(1): 25-46. https://doi.org/10.1515/danb-2015-0002

Laužikas, M.; Miliūtè, A.; Tranavičius, L.; Kičiatovas, E. 2016. Service Innovation Commercialization Factors in the Fast Food Industry, Entrepreneurship and Sustainability Issues 4(2): 108-128. http://dx.doi.org/10.9770/jesi.2016.4.2(1)

Lawson B.; Samson, D. 2001. Developing innovation capability in organizations: a dynamic capabilities approach, International Journal of Innovation Management 3(5): 377-400.

Lihonenko, L.O. Tekhnolohichnyi rozvytok pidpryiemstva yak obyekt upravlinnia. Available on the Internet $<$ http://eir.pstu.edu/bitstream/handle/123456789/12328/7.pdf?sequence=1 2016>.

Lisin, E.; Strielkowski, W. 2014. Modelling new economic approaches for the wholesale energy markets in Russia and the EU, Transformations in Business and Economics 13(2B): 566-580.

Mouraud, A. 2017. Innovative time series forecasting: auto regressive moving average vs deep networks, Entrepreneurship and Sustainability Issues 4(3): 282-293. http://dx.doi.org/10.9770/jesi.2017.4.3S(4)

Perfido, D.; Raciti, M.; Zanotti, C.; Chambers, N.; Hannon, L.; Keane, M.; Clifford, E.; Costa, A. 2017. Towards sustainable water networks: automated fault detection and diagnosis, Entrepreneurship and Sustainability Issues 4(3): 339-350. http://dx.doi.org/10.9770/ jesi.2017.4.3S(9)

Razminienė, K.; Tvaronavičienè, M.; Zemlickienè, V.. 2016. Evaluation of cluster efficiency tool, Terra Economicus 14(3): 101-111. http://dx.doi.org/10.18522/2073-6606-2016-14-3-101-111

Rezk, M. A.; Ibrahim, H. H.; Tvaronavičienè, M.; Sakr, M. M.; Piccinetti, L. 2015. Measuring innovations in Egypt: case of industry, Entrepreneurship and Sustainability Issues 3(1): 47-55. http://dx.doi.org/10.9770/jesi.2015.3.1(4)

State Statistics Service of Ukraine 2016. Available on the Internet <http://www.ukrstat.gov.ua/operativ/operativ2007/ibd/voz/voz_u/ voz06_u. htm>.

Strielkowski, W.; Weyskrabova, B. 2014. Ukrainian labour migration and remittances in the Czech Republic, Tijdschrift voor economische en sociale geografie 105(1): 30-45. https://doi.org/10.1111/tesg.12052

Tvaronavičienè, M. 2016. Start-ups across the EU: if particular tendencies could be trace, Entrepreneurship and Sustainability Issues 3(3): 290-298. http://dx.doi.org/10.9770/jesi.2016.3.3(6)

Tvaronavičienè, M.; Černevičiūtè, J. 2015. Technology transfer phenomenon and its impact on sustainable development, Journal of Security and Sustainability Issues 5(1): 87-97. http://dx.doi.org/10.9770/jssi.2015.5.1(7)

Tvaronavičienė, M.; Razminienė, K.; Piccinetti, L. 2015. Aproaches towards cluster analys, Economics \& Sociology : journal of scientific papers 8(1): 19-27.

Tvaronavičienė, M.; Razminienė, K.; Piccinetti, L. 2015a. Cluster efficiency study through benchmarking, Entrepreneurship and Sustainability Issues 3(2): 120-128. http://dx.doi.org/10.9770/jesi.2015.3.2(0)

Ukrainian National Competitiveness Report 2013. Available on the Internet <http://www.feg.org.ua/en/>.

Yefremov, O.S. 2012. Upravlinnia innovatsiinym rozvytkom pidryiemstva: aspekty metodolohii. Luhansk: SNU im. V. Dalia.

\section{Alexandr TELETOV}

ORCHID ID: http://orcid.org/0000-0001-9977-2294

\section{Yeugene NAGORNYI}

ORCHID ID: http://orcid.org/0000-0003-0756-8398

\section{Nataliia LETUNOVSKA}

ORCHID ID: http://orcid.org/0000-0001-8207-9178

\section{Olena SHEVLIUGA}

ORCHID ID: http://orcid.org/0000-0001-5863-9649 